\title{
Gasification of sunflower seed pulp for the synthesis of hydrogen-rich products
}

\author{
Tolga K. Kanatli ${ }^{\mathrm{a}}$, Nezihe Ayas ${ }^{\mathrm{a}, *}$ \\ ${ }^{a}$ Department of Chemical Engineering, Faculty of Engineering, Eskişehir Technical University, 2 Eylul Campus, Eskişehir, 26555 \\ Turkey
}

\begin{abstract}
Gasification of biomass has great potential for satisfying the ever-growing demand for a clean and renewable energy source. In this study, sunflower seed pulp, a waste product of sunflower oil factories, was gasified using $\mathrm{K}_{2} \mathrm{CO}_{3}$ as a catalyst and dry air as a gasifying agent. Effects of reaction temperature, dry air flow rate and catalyst ratio on the gas product composition were investigated. The highest hydrogen yield $(5.45 \mathrm{~mol} / \mathrm{kg}$ biomass $)$ was achieved at $750{ }^{\circ} \mathrm{C}$, with the addition of $20 \mathrm{wt} . \% \mathrm{~K}_{2} \mathrm{CO}_{3}$ and with a dry air flow rate of $3 \mathrm{~L} / \mathrm{h}$.
\end{abstract}

Keywords: Gasification, hydrogen, sunflower seed pulp, sunflower meal

\section{Introduction}

Worlds energy demand is being satisfied mostly with petroleum fuels, coal and natural gas. It has been realized that those sources are unsustainable and have harmful effects on the environment. Therefore, the search for cleaner and more reliable, renewable energy sources has gained a lot more importance recently [1]. Hydrogen is a promising, clean and renewable power source. Three main methods of producing hydrogen-rich gas are pyrolysis, catalytic steam reforming and gasification [2].

Hydrogen is mainly produced through natural gas reforming, which is a costly process [3]. According to market research in 2018 , high purity hydrogen costs approx. $8 \$ / \mathrm{kg} \mathrm{H}_{2}$ which equates to $66.4 \$ / \mathrm{GJ}$ energy produced.

This study aims to reduce the cost of hydrogen production through the gasification of sunflower seed pulp (sunflower meal/sunflower oil cake), which is a waste biomass of sunflower oil factories. Most of the leftover pulp after oil extraction is being used as fodder or fuel without any treatment [4].

The gasification method yields gaseous products with higher hydrogen to carbon ratio than other methods like pyrolysis. The hydrogen-rich gases produced from the biomass can be purified or combusted on-site to produce electricity for powering sunflower oil factories.

There is limited research in the literature about the gasification of sunflower seed pulp. According to the 2013 data, the annual sunflower seed production rate of Turkey is 1380000 tons. Zabaniotou et al. have performed pyrolysis of sunflower seed pulp at 300-600 ${ }^{\circ} \mathrm{C}, 1 \mathrm{~atm}$, under helium atmosphere. They reported that the highest gas yield (53\% wt. gas/wt. biomass) was obtained with a gas flow rate of 50 $\mathrm{cm}^{3} / \mathrm{min}$, a heating rate of $40{ }^{\circ} \mathrm{C} / \mathrm{s}$ and a reaction temperature of $500{ }^{\circ} \mathrm{C}$ [5].

Christodoulou et al. gasified sunflower seed pulp using a continuous fluidized bed reactor. Highest hydrogen composition ( 28.6 vol.\%) was achieved at $800{ }^{\circ} \mathrm{C}, 1 \mathrm{~atm}$. Biomass and air feed rates, and total gas product flow rates were $6.8 \mathrm{~kg} / \mathrm{h}, 7.8 \mathrm{~m}^{3} / \mathrm{h}$, and $15.61 \mathrm{~m}^{3} / \mathrm{h}$, respectively, which is approximately equal to $7.46 \mathrm{~mol} \mathrm{H}_{2} / \mathrm{kg}$ biomass [6].

\footnotetext{
* Manuscript received February 2, 2018; revised January 3, 2019.

Corresponding author. Tel.: +90-222-321-35-50 (6506); E-mail address: neziheayas@ gmail.com

doi: 10.12720 /sgce.8.2.226-230
} 
Shie et al. investigated the effect of $\mathrm{K}_{2} \mathrm{CO}_{3}$ on the pyrolysis of sunflower seed pulp using a $60 \mathrm{~kW}$ pilot-scale plasma torch reactor at $1 \mathrm{~atm}, 700^{\circ} \mathrm{C}$, and with an $\mathrm{N}_{2}$ flow rate of $100 \mathrm{~L} / \mathrm{min}$. It was determined that the addition of 20 wt. $\% \mathrm{~K}_{2} \mathrm{CO}_{3}$ yields to $\mathrm{H}_{2}, \mathrm{CO}$ and $\mathrm{CH}_{4}$ concentrations of 44.31, 42.91 and 12.76 vol.\%, respectively [7].

In the literature, reported values of lignin and hemicellulose content of sunflower seed pulp vary between $6.1 \%-26.8 \%$ and $12.6 \%-33.3 \%$ respectively. No data regarding the benzene-ethanol extractive content of this particular biomass was found. However, the extractive content of the sunflower seed hulls varies between $0 \%-5.3 \%$ [8-11].

\section{Materials and Methods}

\subsection{Material}

Sunflower seed pulp was obtained from an oil factory located in western Turkey. High purity $\mathrm{K}_{2} \mathrm{CO}_{3}$ and dry air were used in the experiments.

\subsection{Equipment}

An updraft gasifier was used for the gasification of biomass. The gasifier is a $900 \mathrm{~mm}$ long, 316 stainless steel tube with an internal diameter of $10 \mathrm{~mm}$. An external power supply allows the reactor to heat up to $850^{\circ} \mathrm{C}$ in 60 seconds. The reactor has a removable ceramic outer shell for heat insulation.

Products are separated by a liquid-gas separator. The gaseous product goes through the moisture and particle filters before the gas sampling bag. The dry air flow rate is regulated by a standard flow meter (Fig. 1).

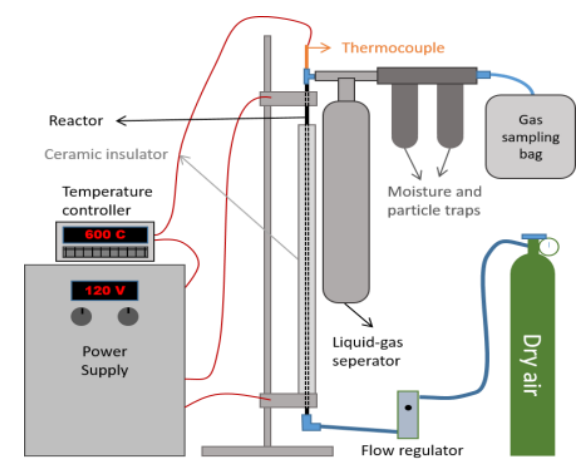

Fig. 1. Experimental setup.

Analysis of the product-gas was done using an SRA Technologies Micro Gas Chromatograph ( $\mu$-GC) (T-3000 series) equipped with MS5A (Molecular sieves $5 \AA$ ) and PPQ (PolarPlot Q) columns coupled to thermal conductivity detectors (TCD). A standard gas mixture was used to calibrate the $\mu$-GC. Helium and argon were used as carrier gases.

\subsection{Experimental procedure}

Prior to any experiment, air dried biomass was milled in a rotary cutter mill at 8000 RPM and then dried at $105^{\circ} \mathrm{C}$ for $24 \mathrm{~h}$.

\subsubsection{Proximate analysis}

Proximate analysis was performed on the biomass using standard methods [12,13]. According to the analysis results, it contains $4.47 \%$ moisture, $1.48 \%$ extractives, $69 \%$ hemicellulose and $18.5 \%$ lignin.

\subsubsection{Gasification of sunflower seed pulp}

The biomass was gasified using an updraft gasifier. Experiments were conducted at different temperatures $\left(650,750\right.$ and $\left.850{ }^{\circ} \mathrm{C}\right)$, catalyst to biomass ratios $(0,20$ and $40 \%$ wt./wt.) and dry air flow 
rates $(1,2,3$ and $4 \mathrm{~L} / \mathrm{h})$ to determine suitable reaction parameters.

For each experiment, $3 \mathrm{~g}$ of biomass was mixed with the catalyst $\left(\mathrm{K}_{2} \mathrm{CO}_{3}\right)$ at desired ratios and placed into the reactor between two layers of wire mesh filter as a fixed bed. Then, the reactor was inserted into the ceramic insulator shell. After that, the liquid/gas separator and the dry air inlet pipe were connected to the reactor. The reactor temperature was adjusted with a temperature controller unit. After the setup procedure, the external power source was switched on to start the reaction. The temperature controller was set to reach the desired temperature in three minutes. Experiments were carried out at a constant reaction time of 15 minutes and $1 \mathrm{~atm}$. Gaseous products were collected in the gas sampling bag and then introduced into the $\mu$-GC in order to find out the gas composition.

\section{Results and Discussion}

The effects of reaction temperature, dry air flow rate, and catalyst ratio on the product-gas yield were determined. Component yields of carbon monoxide $(\mathrm{CO})$, carbon dioxide $\left(\mathrm{CO}_{2}\right)$ and hydrogen $\left(\mathrm{H}_{2}\right)$ in the product-gases of each experiment were determined. The total yield of methane $\left(\mathrm{CH}_{4}\right)$, ethane $\left(\mathrm{C}_{2} \mathrm{H}_{6}\right)$, ethylene $\left(\mathrm{C}_{2} \mathrm{H}_{4}\right)$, propylene $\left(\mathrm{C}_{3} \mathrm{H}_{6}\right)$ and propane $\left(\mathrm{C}_{3} \mathrm{H}_{8}\right)$ were also determined and reported as $\mathrm{C}_{n} \mathrm{H}_{\mathrm{n}}$.

\subsection{Effect of reaction temperature}

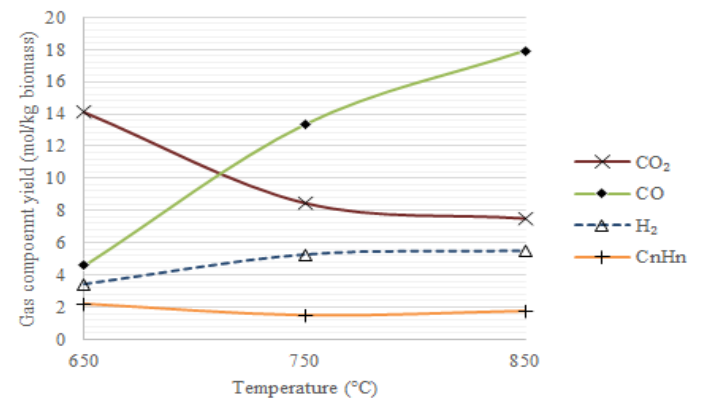

Fig. 2. Effect of temperature on gas yields @ 3 L/h dry air input rate, without any catalyst.

According to Fig. 2, hydrogen yield increases with temperature by approx. 60\%. A similar increase can be observed in carbon monoxide, which almost quadruples. He et al. found similar results and it was explained by Le Chatelier's principle [14].

The highest hydrogen $(5.49 \mathrm{~mol} / \mathrm{kg}$ biomass $)$, methane $(1.43 \mathrm{~mol} / \mathrm{kg}$ biomass $)$ and carbon monoxide ( $17.92 \mathrm{~mol} / \mathrm{kg}$ biomass) yields, as well as the lowest carbon dioxide $(7.48 \mathrm{~mol} / \mathrm{kg}$ biomass $)$, ethane $(0.14$ $\mathrm{mol} / \mathrm{kg}$ biomass), ethylene $(0.078 \mathrm{~mol} / \mathrm{kg}$ biomass), propylene and propane (both around $0.05 \mathrm{~mol} / \mathrm{kg}$ biomass) yields were achieved at $850^{\circ} \mathrm{C}$.

\subsection{Effect of dry air flow rate}

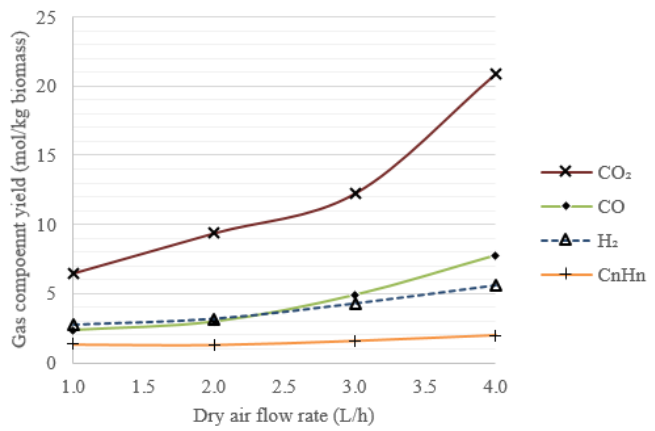

Fig. 3. Effect of dry air feed rate on gas yields @ $20 \mathrm{wt} . \% \mathrm{~K}_{2} \mathrm{CO}_{3}, 650{ }^{\circ} \mathrm{C}$. 
Fig. 3 illustrates that hydrogen yield increases steadily with the dry air flow rate since the stoichiometry of the reactions that favor the hydrogen production are satisfied adequately. The molar composition of hydrogen decreases by $3 \%$ and $20 \%$ at the flowrates of $3 \mathrm{~L} / \mathrm{h}$ and $4 \mathrm{~L} / \mathrm{h}$ respectively because of the inert nitrogen gas in the dry air mixture. Having a diluted product-gas could potentially increase the cost of purification; therefore the suitable flowrate was determined as $3 \mathrm{~L} / \mathrm{h}$. At this condition, hydrogen, methane and carbon monoxide yields increase by $57 \%, 45 \%$ and $168 \%$ respectively.

The highest hydrogen $(5.63 \mathrm{~mol} / \mathrm{kg}$ biomass $)$, carbon monoxide $(7.75 \mathrm{~mol} / \mathrm{kg}$ biomass $)$, carbon dioxide ( $20.87 \mathrm{~mol} / \mathrm{kg}$ biomass), methane $(1.072 \mathrm{~mol} / \mathrm{kg}$ biomass $)$, ethane $(0.37 \mathrm{~mol} / \mathrm{kg}$ biomass $)$, propane $(0.15$ $\mathrm{mol} / \mathrm{kg}$ biomass $)$ and propylene $(0.17 \mathrm{~mol} / \mathrm{kg}$ biomass $)$ yields were obtained using a dry air flow rate of $4 \mathrm{~L} / \mathrm{h}$ with the lowest ethylene yield of $0.19 \mathrm{~mol} / \mathrm{kg}$ biomass.

\subsection{Effect of catalyst to biomass ratio}

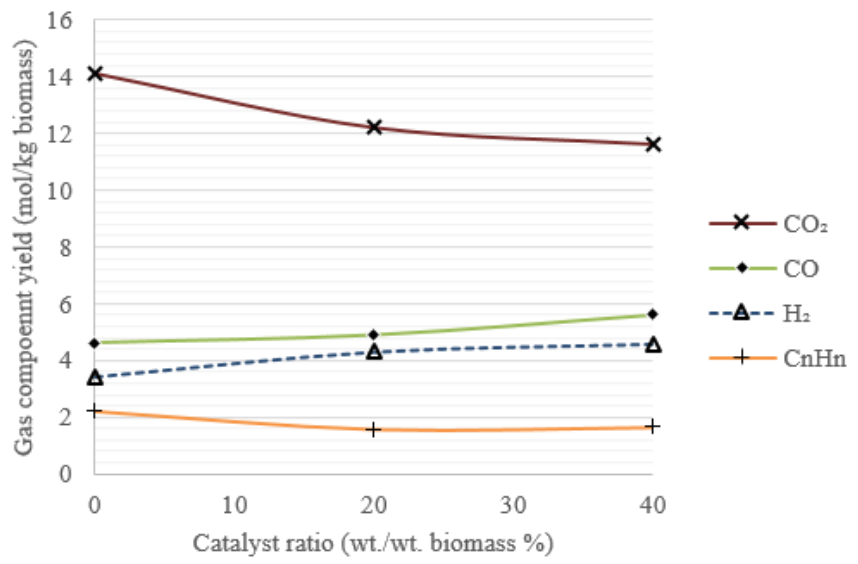

Fig. 4. Effect of $\mathrm{K}_{2} \mathrm{CO}_{3}$ to biomass ratio on gas yields @ $650{ }^{\circ} \mathrm{C}, 3 \mathrm{~L} / \mathrm{h}$ dry air flow rate.

Fig. 4 shows that hydrogen and carbon monoxide yields increase with the catalyst ratio up to 4.59 and $5.63 \mathrm{~mol} / \mathrm{kg}$, respectively. The yields of ethylene, ethane, propylene, and propane, as well as carbon dioxide decrease with higher catalyst ratios. Demirbas reported that the use of $\mathrm{K}_{2} \mathrm{CO}_{3}$ can prevent the formation of stable chemical structures in the products and weaken the $\mathrm{C}-\mathrm{C}$ bond by an oxygen transfer mechanism, thus decreasing the activation energy of the complex pyrolysis reaction [15]. This phenomenon might be the cause of the decrease in $\mathrm{C}_{2+n}$ components.

The increase in hydrogen yield between the catalyst ratios of $20 \%$ and $40 \%$ is only $6 \%$; therefore it might be more economical to use a catalyst ratio of $20 \%$.

When $20 \%$ catalyst ratio was used at 750 and $850{ }^{\circ} \mathrm{C}$, the hydrogen yields were observed to be 5.48 and $7.11 \mathrm{~mol} / \mathrm{kg}$ biomass, respectively. These findings are similar to what Christodoulou et al. reported $\left(7.41 \mathrm{~mol} / \mathrm{kg}\right.$ at $\left.850{ }^{\circ} \mathrm{C}\right)$ under the same conditions[6]. The slight surplus in their hydrogen yield is most probably caused by their use of a continuous reactor, instead of a batch reactor.

\section{Conclusion}

In this research utilization of sunflower seed pulp was investigated in order to obtain hydrogen-rich gaseous products. Effect of gasification reaction parameters such as temperature $\left(650,750,850{ }^{\circ} \mathrm{C}\right)$, airflow rate $(1,2,3,4 \mathrm{~L} / \mathrm{h})$ and catalyst ratio $(0,10,20,30,40 \%)$ on the hydrogen yield was examined.

The hydrogen yield of the studies carried out without catalyst at $850{ }^{\circ} \mathrm{C}$ and with $20 \% \mathrm{~K}_{2} \mathrm{CO}_{3}$ catalyst at $750{ }^{\circ} \mathrm{C}$ were found to be 5.49 and $5.45 \mathrm{~mol} / \mathrm{kg}$ biomass, respectively. Since these values are almost the same, the appropriate operating condition was determined as $750{ }^{\circ} \mathrm{C}$ using $20 \% \mathrm{~K}_{2} \mathrm{CO}_{3}$ and air flow rate of $3 \mathrm{~L} / \mathrm{h}$. 


\section{Acknowledgment}

This study was supported by Eskisehir Technical University Scientific Research Projects Commission under the grant no: $1708 \mathrm{~F} 484$.

\section{References}

[1] Effendi A, Gerhauser H, Bridgwater AV. Production of renewable phenolic resins by thermochemical conversion of biomass: A review. Renewable and Sustainable Energy Reviews, 2008; 12(8):2092-2116.

[2] Cortright RD, Davda RR, Dumesic JA. Hydrogen from catalytic reforming of biomass-derived hydrocarbons in liquid water. Nature, 2002; 418(6901):964-967.

[3] US Department of Energy. (March 2018). Hydrogen Production Pathways [Internet]. Available: https://www.energy.gov/eere/fuelcells/hydrogen-production-pathways

[4] Tmmob Ziraat Mühendisleri Odasi. (December 2017). Ayçiçeği Ve Ayçiçek Yaği Üretimi, İthalati Ve Sorunlari [Internet]. 2013; Available: http://www.zmo.org.tr/genel/bizden_detay.php?

[5] Zabaniotou AA, Kantarelis EK, Theodoropoulos DC. Sunflower shells utilization for energetic purposes in an integrated approach of energy crops: Laboratory study pyrolysis and kinetics. Bioresource Technology, 2008; 99(8):3174-3181.

[6] Christodoulou C, Grimekis D, Panopoulos KD, Vamvuka D, Karellas S, Kakaras E. Circulating fluidized bed gasification tests of seed cakes residues after oil extraction and comparison with wood. Fuel, 2014; 132:71-81.

[7] Shie JL, Chang CC, Chang CY, Tzeng CC, Wu CY, Lin KL, et al. Co-pyrolysis of sunflower-oil cake with potassium carbonate and zinc oxide using plasma torch to produce bio-fuels. Bioresource Technology, 2011; 102(23):11011-11017.

[8] Heuzé V, Tran G, Hassoun P, Lessire M, Lebas F. (December 2017). Sunflower meal [Internet]. Feedipedia, a programme by INRA, CIRAD, AFZ and FAO2014; Available: https://www.feedipedia.org/node/732

[9] Camargo D, Sene L. Production of ethanol from the hemicellulosic fraction of sunflower meal biomass. Biomass Conversion and Biorefinery, 2014; 4(2):87-93.

[10] Sirisomboon K, Charernporn P. Effects of air staging on emission characteristics in a conical fluidized-bed combustor firing with sunflower shells. Journal of the Energy Institute, 2017; 90(2):316-323.

[11] Bilgic E, Yaman S, Haykiri-Acma H, Kucukbayrak S. Limits of variations on the structure and the fuel characteristics of sunflower seed shell through torrefaction. Fuel Processing Technology, 2016; 144:197-202.

[12] Li S, Xu S, Liu S, Yang C, Lu Q. Fast pyrolysis of biomass in free-fall reactor for hydrogen-rich gas. Fuel Processing Technology, 2004; 85(8-10):1201-1211.

[13] Helrich K. Official Method of Analysis of the AOAC. Association of Official Analytical Chemists, Arlington, Va, USA, 1990;

[14] He M, Xiao B, Hu Z, Liu S, Guo X, Luo S. Syngas production from catalytic gasification of waste polyethylene: Influence of temperature on gas yield and composition. International Journal of Hydrogen Energy, 2009; 34(3):1342-1348.

[15] Demirbas A. Kinetics for non-isothermal flash pyrolysis of hazelnut shell. Bioresource Technology, 1998; 66(3):247-252. 